Favored Flowers 



\section{FAVORED FLOWERS}

Culture and Economy in a Global System

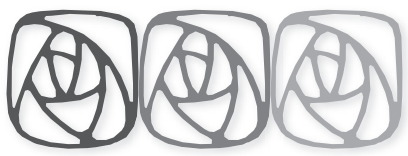

Catherine Ziegler

DUKE UNIVERSITY PRESS

DURHAM \& LONDON 2007 
(C) 2007 Duke University Press

All rights reserved

Printed in the United States of America on acid-free paper $\infty$ Designed by Jennifer Hill

Typeset in Adobe Garamond Pro by Keystone Typesetting, Inc. Library of Congress Cataloging-in-Publication Data appear on the last printed page of this book. 